\title{
Algal growth and weathering crust state drive variability in western Greenland Ice Sheet ice albedo
}

\author{
Andrew J. Tedstone ${ }^{1,2}$, Joseph M. Cook ${ }^{3,4}$, Christopher J. Williamson ${ }^{1}$, Stefan Hofer ${ }^{1}$, Jenine McCutcheon ${ }^{5}$, \\ Tristram Irvine-Fynn ${ }^{6}$, Thomas Gribbin ${ }^{1}$, and Martyn Tranter ${ }^{1}$ \\ ${ }^{1}$ Bristol Glaciology Centre, School of Geographical Sciences, University of Bristol, Bristol, UK \\ ${ }^{2}$ Department of Geosciences, University of Fribourg, Fribourg, Switzerland \\ ${ }^{3}$ Department of Geography, University of Sheffield, Sheffield, UK \\ ${ }^{4}$ Institute of Biological, Environmental and Rural Sciences, Aberystwyth University, Aberystwyth, UK \\ ${ }^{5}$ School of Earth and Environment, University of Leeds, Leeds, UK \\ ${ }^{6}$ Department of Geography and Earth Sciences, Aberystwyth University, Aberystwyth, UK
}

Correspondence: Andrew J. Tedstone (andrew.tedstone@unifr.ch)

Received: 31 May 2019 - Discussion started: 15 July 2019

Revised: 28 November 2019 - Accepted: 6 January 2020 - Published: 11 February 2020

\begin{abstract}
One of the primary controls upon the melting of the Greenland Ice Sheet (GrIS) is albedo, a measure of how much solar radiation that hits a surface is reflected without being absorbed. Lower-albedo snow and ice surfaces therefore warm more quickly. There is a major difference in the albedo of snow-covered versus bare-ice surfaces, but observations also show that there is substantial spatio-temporal variability of up to $\sim 0.4$ in bare-ice albedo. Variability in bare-ice albedo has been attributed to a number of processes including the accumulation of light-absorbing impurities (LAIs) and the changing physical properties of the nearsurface ice. However, the combined impact of these processes upon albedo remains poorly constrained. Here we use field observations to show that pigmented glacier algae are ubiquitous and cause surface darkening both within and outside the south-west GrIS "dark zone" but that other factors including modification of the ice surface by algal bloom presence, surface topography and weathering crust state are also important in determining patterns of daily albedo variability. We further use observations from an unmanned aerial system (UAS) to examine the scale gap in albedo between ground versus remotely sensed measurements made by Sentinel-2 (S-2) and MODIS. S-2 observations provide a highly conservative estimate of algal bloom presence because algal blooms occur in patches much smaller than the ground resolution of S-2 data. Nevertheless, the bare-ice albedo distribution at the scale of $20 \mathrm{~m} \times 20 \mathrm{~m} \mathrm{~S}-2$ pixels is generally unimodal and
\end{abstract}

unskewed. Conversely, bare-ice surfaces have a left-skewed albedo distribution at MODIS MOD10A1 scales. Thus, when MOD10A1 observations are used as input to energy balance modelling, meltwater production can be underestimated by $\sim 2 \%$. Our study highlights that (1) the impact of the weathering crust state is of similar importance to the direct darkening role of light-absorbing impurities upon ice albedo and (2) there is a spatial-scale dependency in albedo measurement which reduces detection of real changes at coarser resolutions.

\section{Introduction}

The Greenland Ice Sheet (GrIS) has experienced $\sim 2{ }^{\circ} \mathrm{C}$ of summer warming since the mid-1990s, increasing runoff by more than $40 \%$ without concomitant increases in precipitation (van den Broeke et al., 2017). Since approximately 2010 the total mass imbalance has been dominated by melting and runoff, corresponding to $68 \%$ of mass losses between 2009 and 2012 (Enderlin et al., 2014). This is especially important on the western side of the ice sheet, where the majority of meltwater runs off directly into the ocean rather than refreezing (Steger et al., 2017). Enhanced melting has been caused by recent persistent anticyclonic summer conditions (Fettweis et al., 2013), which reduce cloud cover, leading to enhanced shortwave radiation over the ablation zone (Hofer 
et al., 2017). Mass loss from the GrIS accounted for $37 \%$ of cryospheric sea level rise from 2012 to 2016 (Bamber et al., 2018), so it is therefore critical to understand the contribution of surface melting and runoff to GrIS mass loss.

Melting is principally controlled by net shortwave radiation, which in turn is modulated by surface albedo. Loweralbedo snow and ice absorb more energy, leading to faster melting and more runoff. Since around 2000 the albedo in several GrIS sectors has declined, especially along the western margins, where albedo reduced by as much as $9 \%$ between 2000 and 2017 (van den Broeke et al., 2017). Some of this change can be attributed to winter snowpack melting earlier in the summer, revealing lower-albedo ice (Ryan et al., 2019), but observations of surface albedo and reflectance made over the past $\sim 20$ years also show an overall increase in the extent and magnitude of "dark" ice as distinct from clean bare-ice surfaces (Shimada et al., 2016; Tedstone et al., 2017). Albedo is one of the largest uncertainties in energy balance modelling (Hock, 2005; Noël et al., 2015). Models generally fail to capture the magnitude of the albedo reductions which have occurred in "dark" areas, probably because light-absorbing impurities (LAIs) are not presently included in model albedo schemes (Tedesco et al., 2016).

Despite previous studies inferring the potential albedoreducing importance of impurities including cryoconite, emergent dust and liquid meltwater (Greuell, 2000; Bøggild et al., 2010; Wientjes and Oerlemans, 2010), there is an emerging consensus that pigmented glacier algae grow on the ice surface (Uetake et al., 2010; Yallop et al., 2012; Stibal et al., 2017; Williamson et al., 2018) and are the dominant agent of darkening amongst LAIs (Stibal et al., 2017; Tedstone et al., 2017; Cook et al., 2019b). Glacier algae reduce albedo both directly (i.e. the cells absorb shortwave radiation) and indirectly by modifying the underlying ice surface, for instance by maintaining a liquid water film (Cook et al., 2017, 2019b; Williamson et al., 2019). They are ubiquitous across south-western Greenland (Cook et al., 2019b; Wang et al., 2018). Their growth is principally controlled by (i) the timing of winter snowpack retreat, (ii) meltwater availability and (iii) sufficient photosynthetically active radiation (Williamson et al., 2019).

The state of the uppermost surface ice itself, however, is also important in determining albedo. When shortwave radiative energy fluxes dominate, a porous, low-density weathering crust develops as a consequence of radiative energy penetration to the sub-surface (Muller and Keeler, 1969; Munro, 1990). This, together with cryoconite hole formation punctuating the porous substrate (McIntyre, 1984; Cook et al., 2016), can allow supraglacially generated meltwater to drain into a shallow, depth-limited sub-surface water table (IrvineFynn et al., 2011; Cooper et al., 2018; Christner et al., 2018). This porous near-surface ice layer typically has numerous air-ice interfaces characterized by a rough surface topography, offering opportunities for high-angle light scattering, which increases albedo (Jonsell et al., 2003). Conversely, during periods of overcast, warm and windy weather, the low-density weathering crust will melt away, leaving a hard and glazed ice surface (Muller and Keeler, 1969). Thus, during periods of weathering crust formation, surface lowering measurements will underestimate actual ablation rates, but during periods of weathering crust stripping, measured ablation rates will appear unusually large (Muller and Keeler, 1969; Schuster, 2001).

It is difficult to identify the emergent processes that control bare-ice albedo over landscape scales because there is a disconnect between the centimetre scales of groundbased spectroscopy versus remote sensing over hundreds of metres by satellite platforms such as MODIS. Groundbased spectroscopy in the south-west dark zone during the 2012 and 2013 seasons showed bare-ice albedo variability of $10 \%-30 \%$ and that dirty ice introduced a left skew in the albedo distribution of transect-based measurements (Moustafa et al., 2015). Single-point-to-satellite-pixel validation is inadequate, as there are large in situ deviations from coarser-scale satellite albedo measurements, so multiplepoint-to-pixel approaches are needed to capture spatial variability (Moustafa et al., 2017; Ryan et al., 2017).

Unmanned aerial systems (UASs) provide one way to bridge the scale gap between ground and satellite observations by making high-spatial-resolution measurements over tens of metres to kilometres. This is especially useful for examining heterogeneous distributions in LAIs. For example, on a single day in 2014, LAIs including dust, black carbon and pigmented algae explained $73 \%$ of spatial variability in albedo along a $25 \mathrm{~km}$ transect (Ryan et al., 2018). More recently, combined ground sampling, radiative transfer modelling and surface type classification of UASs and satellite imagery showed that algal blooms specifically can cover at least $78 \%$ of ice in the dark zone, generating at least $6 \%-$ $9 \%$ additional ice melt in the south-west dark zone during the dark year of 2016 compared to the "average" year of 2017 (Cook et al., 2019b). Higher-resolution imagery is therefore able to bridge the scaling gap and has been crucial in demonstrating that glacier algae are the dominant LAI.

Whilst previous studies have made significant advances in understanding spatial variability in albedo, there remain two key challenges: (1) making measurements elsewhere beyond the dark zone and (2) understanding why surface type and bare-ice albedo change through time. Here we present observations of surface type and albedo made by multi-spectral UASs paired with ground sampling at two locations along the western GrIS margin. We examine the drivers of the measured albedo patterns, and at one site we also examine changes in albedo through time and undertake a multiplepoint-to-pixel comparison to assess whether these changes are captured by the Sentinel-2 and MODIS sensors. 


\section{Study sites}

Albedo and surface type measurements were made at two sites in two different years (Fig. 1, inset). During July 2017 we acquired approximately 1 week of measurements at S6 $\left(67.07^{\circ} \mathrm{N}, 49.38^{\circ} \mathrm{W} ; 1073 \mathrm{~m}\right.$ a.s.l.), located within the southwest dark zone approximately $60 \mathrm{~km}$ north-east of Kangerlussuaq and within $2 \mathrm{~km}$ of the IMAU S6 automatic weather station (AWS). We also occupied the site from 31 May to 1 July, enabling us to observe the retreat dynamics of the winter snowpack for most of the early ablation season. UAS imagery acquired on 21 July 2017 has been presented previously (Cook et al., 2019b), but this study is the first to analyse the full time series of UAS imagery that we acquired at S6. During June there were several episodes of snowpack melting, with most of the snowpack retreating by mid-June and exposing bare ice with heterogeneous albedo. However, a series of large snowfall events occurred towards the end of June, and the ice surface was covered by $\sim 10 \mathrm{~cm}$ snow when we left on 1 July. Most snow had melted away when we re-established the site on 13 July for UAS measurements.

We measured surface type and albedo on a single day, 24 July 2018 , at UPE_U $\left(72.88^{\circ} \mathrm{N}, 53.55^{\circ} \mathrm{W}\right.$; $950 \mathrm{~m}$ a.s.1. $)$, hereafter UPE. The site was located in the ablation zone, $26 \mathrm{~km}$ from the ice margin to the east of Upernavik and $\sim 670 \mathrm{~km}$ north of S6, and was within $2 \mathrm{~km}$ of the PROMICE UPE_U AWS. The surface was predominantly bare ice when the field site was established on 21 July. However, there were then several snowfall events which caused a thin layer of snow to obscure much of the ice surface throughout the campaign. Snow fell on 22, 25, 26 and 27 July. Nevertheless, air temperatures exceeded $0{ }^{\circ} \mathrm{C}$ every day between 21 and 27 July, partially melting the snow between each snowfall event.

\section{Data and methods}

\subsection{UAS data}

We mapped a $250 \mathrm{~m} \times 250 \mathrm{~m}$ area of ice surface at each site using the methodology described previously in Cook et al. (2019b). Briefly, we integrated a MicaSense RedEdge multispectral camera onto a SteadiDrone Mavrik-M quadcopter (referred to hereafter as UAS). The camera was remotely triggered through the autopilot, which was programmed along with the flight coordinates in the open-source software Mission Planner. Images were acquired at approximately $2 \mathrm{~cm}$ ground resolution, with $60 \%$ overlap and $40 \%$ side lap. Mapping required two successive flights with a UAS battery change between them. Each flight lasted $\sim 10 \mathrm{~min}$, was made at $30 \mathrm{~m}$ above the ice surface, and took place under clear-sky illumination conditions unless otherwise noted (Appendix A).
At S6 we made UAS flights over several successive days, requiring us to remove the effect of $\sim 0.5-1 \mathrm{md}^{-1}$ of ice motion from the final orthomosaics. We therefore placed 15 ground control points (GCPs) and measured their $X$ and $Y$ locations on 21 July using a differential global navigation satellite system (GNSS) receiver, post-corrected by reference to the Kellyville International GNSS Service (IGS) GNSS station using IGS final orbits. We used the GCPs to constrain the horizontal geo-referencing of every orthomosaic to the same static georectification solution.

We applied radiometric calibration and geometric distortion correction following MicaSense procedures (MicaSense, 2018). We then converted from radiance to reflectance using time-dependent regression between measurements of the MicaSense Calibrated Reflectance Panel (and, at UPE, a Spectralon ${ }^{\circledR}$ panel) acquired before and after each flight. The individual reflectance-corrected images were mosaicked using AgiSoft PhotoScan following the United States Geological Survey (2017), yielding multi-spectral orthomosaics with $5 \mathrm{~cm}$ ground resolution. Finally, the orthomosaics were radiometrically adjusted to match directional reflectance measurements made by ground spectroscopy so that our surface classifier (Sect. 3.5), which was trained using the directional reflectance measurements, could be applied to the orthomosaics.

The orthomosaics were used in three ways: (i) converted to albedo using a narrowband-to-broadband approximation (Knap et al., 1999), (ii) classified into surface types (see Sect. 3.5), and (iii) digital elevation models derived photogrammetrically in Agisoft PhotoScan at $5 \mathrm{~cm}$ ground resolution.

Narrowband-to-broadband approximations for albedo calculations were employed because empirical bi-directional reflectance distribution functions (BRDFs) are not available for the surface types that we mapped. While these surfaces are highly anisotropic, scattering light preferentially in the forward direction (Knap and Reijmer, 1998), there are no datasets we know of that can accurately correct reflectance values gathered at the nadir. We therefore omit a BRDF correction, as existing BRDF datasets cannot be confidently applied to our sample surfaces.

We used the photogrammetric digital elevation models (DEMs) to derive (i) study area slope angle and (ii) local topographic variability. To calculate the slope angle we applied a Gaussian filter with a window of $0.25 \mathrm{~m}$ to remove very high-frequency topographic features; then we calculated the average slope across each study area after Horn (1981), as implemented in the RichDEM library (Barnes, 2016). To examine local topographic variability ("roughness"), we applied a Gaussian filter with a window of $4.95 \mathrm{~m}$ and then subtracted it from the DEM to yield a detrended surface. 


\subsection{Biological sampling}

We took samples of the ice surface at each site to quantify the presence of glacier algal cells. At S6, samples were made immediately after collection of paired ground spectra (Sect. 3.5) to enable direct upscaling by UAS imagery analysis. At UPE, widespread snow cover prevented us from utilizing the paired approach carried out at S6. Instead, on 26 July ( $2 \mathrm{~d}$ after the UAS flight), we cast a random 75-point sampling grid over our UAS flight area. We used a trowel to scrape the snow away to reveal the bare-ice surface beneath for sampling.

Samples were made by cutting a $30 \mathrm{~cm} \times 30 \mathrm{~cm} \times 2 \mathrm{~cm}$ volume out using a metal ice saw and trowel and transferring into a sterile Whirl-Pak bag, which was immediately placed in the dark to melt over a $\sim 24 \mathrm{~h}$ period at ambient air temperature. Following melting, samples were homogenized, sub-sampled into Falcon tubes and fixed with $2 \%$ final-concentration glutaraldehyde. Samples were then returned to laboratories at the University of Sheffield and University of Bristol for counting by microscopic haemocytometers. Full details of the enumeration protocols used are in Cook et al. (2019b, samples from 2017) and Williamson et al. (2018, samples from 2018).

\subsection{Surface lowering}

At S6, we measured daily surface lowering across a total of four plastic ablation stakes drilled into the ice. The poles formed a square $\sim 100 \mathrm{~m} \times 100 \mathrm{~m}$ centred within the wider $250 \mathrm{~m} \times 250 \mathrm{~m}$ UAS survey area. At each pole we took two measurements: one west and one east. Measurements were made between 16:00 and 18:00 local time, except for 17 and 18 July at 12:00 local time and 19 July at 19:45 local time. Here we present daily mean surface lowering calculated from all the poles.

\subsection{Sentinel-2 data}

Clear-sky Sentinel-2 (hereafter S-2) data were available at the S6 site for 20 and 21 July. No clear-sky acquisitions were available, coincident with our field season at the UPE site. We downloaded S-2 L1C data from Sentinel Hub (Sinergise, Slovenia). We used all bands available at 10 and $20 \mathrm{~m}$ resolution by resampling those bands delivered at $10 \mathrm{~m}$ resolution to $20 \mathrm{~m}$ using the S-2 toolbox of the European Space Agency (ESA) SNAP platform. We processed the L1C data to L2A surface reflectance using the ESA Sen2Cor processor. The data were then (i) converted to broadband albedo using a narrowband-to-broadband approximation (Liang, 2001) and (ii) classified into surface types (see Sect. 3.5).

\subsection{Surface type classification}

To classify images by surface type we used a supervised classification approach following Cook et al. (2019b), trained on ground spectra collected at S6 with a FieldSpec Pro 3 (An- alytical Spectral Devices, Boulder, USA) during the 2016 and 2017 field seasons at S6. Briefly, we used 171 directional reflectance measurements. The measurements were labelled by visual examination as snow (SN), water (WA), clean ice (CI), light algae (LA), heavy algae (HA) and dispersed cryoconite $(\mathrm{CC})$. After ground spectra were acquired we took destructive ground samples following procedures in Sect. 3.2. Clean-ice samples contained $625 \pm 381$ cells mL $^{-1}$, light-algae samples $4.73 \times 10^{3} \pm 2.57 \times 10^{3}$ cells mL $^{-1}$ and

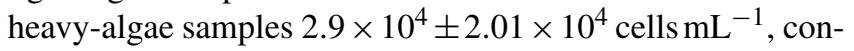
firming the accuracy of our visual assessments of each surface type. We split the dataset randomly into training (70\%) and test $(30 \%)$ sets. These data were used to train a randomforest classifier, which had the highest performance of all classifiers tested (Cook et al., 2019b). We trained the algorithm to predict surface type from (i) our UAS-acquired data, utilizing all five bands of data, and (ii) S-2 data, utilizing all nine bands at $20 \mathrm{~m}$ resolution. The confusion matrices (Appendix B) for the classifiers in this study were similar to those in Cook et al. (2019b). Against the test set, UAS classifier accuracy and recall were both $97 \%$, and S-2 classifier accuracy and recall were both $88 \%$.

\subsection{MOD10A1 data}

We used the albedo retrievals contained within the MODIS/Terra Snow Cover Daily L3 Global $500 \mathrm{~m}$ Grid V006 "MOD10A1" data product (Hall and Riggs, 2016). The two pixels which overlapped with our S6 UAS area were examined in their original sinusoidal projection. Precise overpass times were extracted from the granule pointer information contained within each product file (Appendix A). There were no cloud-free MOD10A1 data available at UPE during our field season.

\subsection{Energy balance and melt modelling}

To provide a local environmental context we used a point surface energy balance model (Brock and Arnold, 2000) to estimate net shortwave and longwave radiation fluxes, the turbulent sensible and latent heat fluxes, and the surface melt rate at a point on a melting ice or snow surface. The model was forced at an hourly time step by continuous measurements of shortwave radiation, vapour pressure, air temperature and wind speed made by IMAU S6 AWS (Kuipers Munneke et al., 2018) and PROMICE UPE_U AWS (van As et al., 2011). We used the albedo measured at each AWS, which at UPE_U was only for solar zenith angles below $70^{\circ}$ and at S6 was only when downwelling shortwave radiation was $>$ $250 \mathrm{~W} \mathrm{~m}^{-2}$; night-time values were therefore forward-filled from the last valid albedo observation. The surface roughness length was held constant at $1 \mathrm{~mm}$, according to similar values for ablating ice surfaces (Brock and Arnold, 2000). Daily melt fluxes were estimated from all time points when the air temperature was $\geq 0{ }^{\circ} \mathrm{C}$. As the AWSs were located a 
few kilometres away, the computed melt rates should be interpreted as indicative of the meteorologically forced melting regime rather than as absolute melt rates experienced across the study areas.

\section{Results and discussion}

\subsection{Impact of glacier algae}

Biological sampling and UAS observations showed that glacier algae were ubiquitous at both S6 and UPE. At S6, low albedo (Fig. 1a) was caused by extensive algal blooming (Fig. 1b) enabled by melting over several preceding weeks (see Cook et al., 2019b). This finding is supported by radiative transfer modelling, which shows that mineral dusts local to S6 are weakly absorbing and strongly scattering, meaning that they locally increase albedo, whereas glacier algae have an albedo-reducing effect (Cook et al., 2019b). At UPE, the albedo was higher (Fig. 1d) due to persistent snow cover obscuring the darker bare-ice surface (Fig. 1e). However, our ground sampling revealed up to $80 \% \mathrm{LA}+\mathrm{HA}$ coverage of the survey area (Appendix C) on the bare-ice surface that was hidden from our aerial remote sensing by a layer of fresh snow. Ultrasonic ranging observations from the UPE_U AWS show that the winter snowpack had melted by 29 June 2018, revealing the bare ice beneath (Fausto and van As, 2019). Between bare-ice exposure and our arrival at the field site the surface had remained snow-free, and our energy balance modelling estimates that $35 \mathrm{~cm}$ w.e. of melt had occurred. These conditions promote algal growth (Yallop et al., 2012; Williamson et al., 2018; Stibal et al., 2017), explaining the presence of algae beneath the recently deposited snow. These observations of spatially expansive populations of algae at both sites demonstrate that biological albedo reduction is important across the ablation zone of the western GrIS, including areas outside of the dark zone.

\subsection{Topographic and hydrologic controls}

The two sites were distinct in their local topography and hydrology. S6 had an average slope of $5^{\circ}$. Topographic features within the area principally consisted of (1) a $\sim 0.3 \mathrm{~m}$ wide ice-incised supraglacial stream and (2) a few isolated small $\left(<2 \mathrm{~m}^{2}\right)$ ice rises up to $\sim 0.2 \mathrm{~m}$ high. After detrending (Sect. 3.1) $99 \%$ of the area had topographic variability of $< \pm 0.05 \mathrm{~m}$ and $54 \%$ of the area was within $\pm 0.01 \mathrm{~m}$. The ice surface to $\sim 300 \mathrm{~m}$ upslope of the area was flatter and had several small moulins, reducing the area contributing to local flow. The shallow and ephemeral arterial hydrological pathways present across the study area during July were likely the result of a constant slope and negligible meltwater routed from upslope, reducing frictional stream incision (Ferguson, 1973). However, during June, winter snowpack retreat caused significant ephemeral water drainage pathways to develop, causing algal-cell concentration and redistribution (e.g. Appendix Fig. D2) until upslope crevasses and moulins opened to route meltwater away englacially. This was likely important in distributing concentrated algal blooms growing in local niches over a wider area given that glacier algae lack a flagellated life stage and so are not independently motile (Williamson et al., 2019).

Observations at UPE where there was substantial local surface roughness (Fig. 2a, b) showed that lower albedos were associated with local depressions (Fig. 2c; $R^{2}=0.71$ with all data; $R^{2}=0.95$ when albedo bins with $<0.5 \%$ area coverage removed). The higher the biomass loading (from $\mathrm{CI}$ through LA to HA), the lower the local elevation of the associated surface was (Fig. 2c). There are at least two possible reasons for the concentration of heavy algae in local depressions. One is entrainment and transport of algal cells in topographically higher areas by meltwater; once the competence of the meltwater flow drops in local depressions, then the impurities will be deposited. Another is that local depressions favour near- or at-surface availability of meltwater through ponding, especially if a weathering crust is well-developed at topographic highs. Surface meltwater reduces albedo (Zuo and Oerlemans, 1996; Greuell, 2000; Greuell et al., 2002), which results in favourable growth conditions for glacier algae (Williamson et al., 2018), further reducing albedo and amplifying surface ablation.

There are strong indications that the local topography and near-surface hydrology at UPE resulted in a different surface state to S6. The shallower slope $\left(1^{\circ}\right)$ than at S6 is likely to favour the evolution of perched meltwater ponds (Fig. 1e), as the lower gravitational potential is less conducive to runoff. Meanwhile, meltwater generated further upglacier flows through the area in streams incised to $\sim 0.6 \mathrm{~m}$ below the mean surface elevation (e.g. the stream running from north-west to south-east through the study area; Fig. 2a). Arterial meltwater pathways are thus likely to persist interannually, as little melting had occurred in the 2018 melt season prior to our measurements (Sect. 4.1). This streamdominated hydrological regime likely reduces the movement of microbial cells suspended in meltwater through the weathering crust (Irvine-Fynn et al., 2012; Cook et al., 2016; Christner et al., 2018) compared to S6. A stream-dominated regime therefore also favours complex spatial and temporal patterns of albedo where most ice is weathered, persistently bright and strongly scattering due to minimal sub-surface meltwater, punctuated by low-albedo melt ponds and concentration of LAIs and water in topographic lows.

\subsection{Changes in ice surface state}

Our S6 field campaign captured a period of storm conditions in the middle of an otherwise shortwave-dominant energy regime, with concomitant impacts upon the ice surface state, including the weathering crust. Energy balance modelling indicates that shortwave energy fluxes dominated the $10 \mathrm{~d}$ preceding the start of our UAS observations on 15 July 

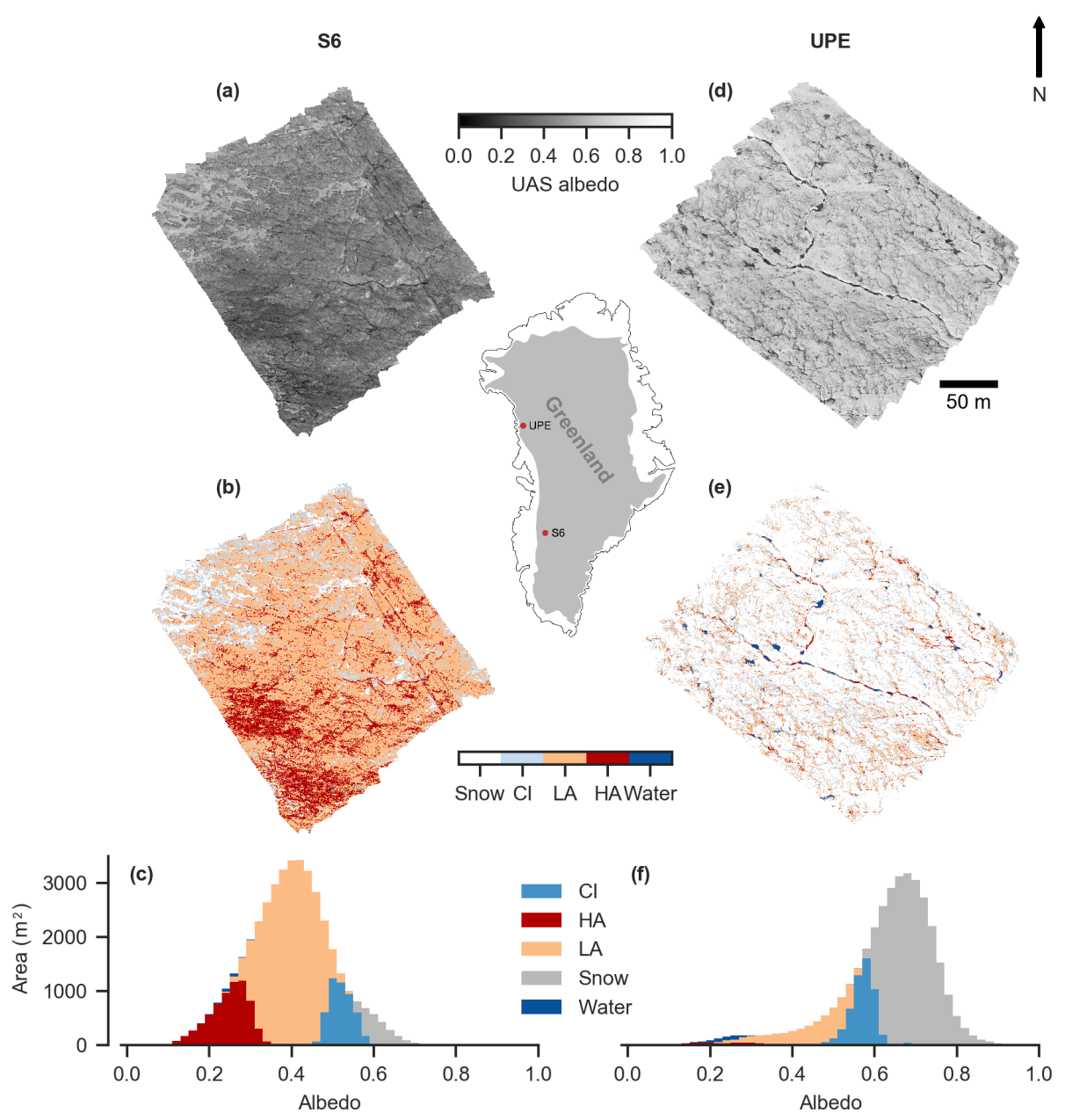

Figure 1. S6 (21 July 2017) and UPE (24 July 2018) UAS study area albedo and surface type. (a) UAS-measured albedo at S6, (b) UASmeasured albedo at UPE, (c) surface type classification at S6, (d) surface type classification at UPE, (e) stacked-bar histogram of surface type coverage at S6 and (f) stacked-bar histogram of surface type coverage at UPE. CI: clean ice. LA: light algae. HA: heavy algae.

(mean daily maximum net shortwave flux: $273 \mathrm{Wm}^{-2}$ ). Oblique photography from 15 July confirms that a weathering crust was ubiquitous throughout the UAS area (Appendix Fig. D1a). During 16-17 July, no melting was modelled (Fig. 3a) or measured (Fig. 3b), and $\sim 5 \mathrm{~cm}$ snow fell on 17 July. During 18-19 July, shortwave energy fluxes remained low while latent and sensible heat fluxes increased (Fig. 3a), associated with strong winds (up to $17.5 \mathrm{~ms}^{-1}$ at S6) and rainfall. We observed substantially more surface lowering (Fig. 3b) than estimated by our model (Fig. 3a). By the evening of 19 July much of the UAS survey area surface had been transformed into flatter, denser ice, overlain in places by ponded meltwater (Appendix Fig. D1b). The remainder of our field campaign saw a return to shortwave-dominant energy balance conditions. Sub-surface melting presumably dominated ablation, as no significant surface lowering occurred (Fig. 3c) despite relatively large modelled melt fluxes (Fig. 3b), resulting in weathering crust (re-)development (Appendix Fig. D1c).
We propose that changes in weathering crust state can be diagnosed through repeat measurements of reflectance in the near-infrared (NIR) part of the spectrum made by our UAS, centred on $840 \mathrm{~nm}$. Absorption by LAIs such as glacier algae is concentrated in the visible part of the solar spectrum, while at $840 \mathrm{~nm}$ the albedo-reducing effect of glacier algae and other impurities are negligible (Cook et al., 2017, 2019b, a; Williamson et al., 2019), and so by deduction variations in the NIR are primarily due to changes in near-surface ice properties. Whilst there may be some residual reflectance reduction attributable to black carbon (Warren, 1984), by deduction, the dominant signal retrieved at $840 \mathrm{~nm}$ by our UAS is indicative of the weathering crust state, inclusive of ice grain sizes, ice density, porosity, and interstitial and ponded surface meltwater. Reflectance at $840 \mathrm{~nm}$ thus essentially provides an indication of the presence or absence of air-ice interfaces available for high-angle light scattering, whereby more interfaces result in higher albedo (Jonsell et al., 2003). 

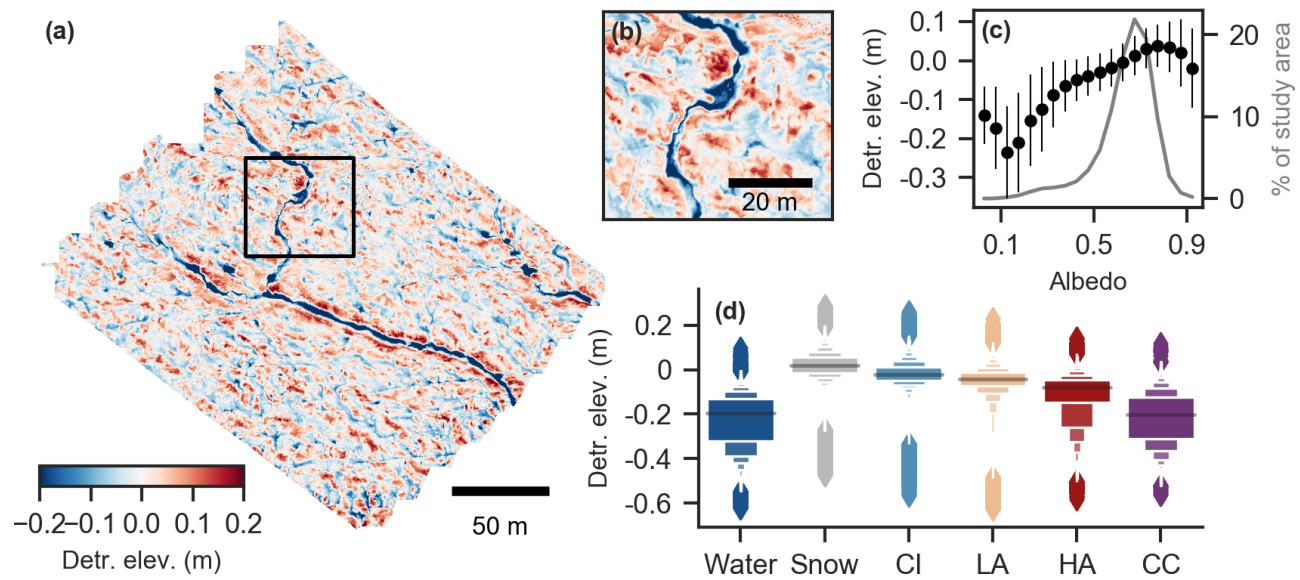

Figure 2. Surface topography variability at UPE. (a) Detrended elevation ("roughness"). Black box delineates the area shown in panel (b). (b) Zoomed detail of detrended elevation, showing incised supraglacial stream and the pattern of local topographic highs and lows. (c) Median detrended elevation in each $5 \%$ albedo bin $\pm 1 \sigma$ (left axis) and percentage coverage of each albedo bin (gray line; right axis). (d) Letter plots of detrended elevation for each surface type, illustrating median (black line), distribution of elevation values (boxes) and outliers (diamonds) within each category (Hofmann et al., 2011), computed from whole area shown in (a).

UAS observations from S6 show a widespread increase in $840 \mathrm{~nm}$ reflectance between 20 July and 21 July (Fig. 4a). True-colour UAV composites illustrate a transition from wet, polished and impermeable ice surfaces (Fig. 4c, f) to drained, whiter ice with meltwater draining through the porous nearsurface (Fig. 4d, g), also shown by oblique surface photos (Appendix Fig. D1b, c). This change was coincident with the surface energy balance returning to a shortwavedominant regime following $4 \mathrm{~d}$ of dramatically reduced net shortwave radiation (Fig. 3a) and 1-2 d of rainfall. Following regrowth of the weathering crust and drainage of ponded meltwater there were no further systematic changes in NIR reflectance (Fig. 4b) or true-colour composites (Fig. 4d, e). These findings are consistent with previous studies showing that weathering crust development versus decay is controlled primarily by the relative dominance of radiative or turbulent fluxes in the surface energy budget (Muller and Keeler, 1969; Schuler, 2004). Further, the reduction of albedo by rainfall through weathering crust stripping means that the meltgenerating potential of cyclonic moisture intrusions which have been shown to account for $\sim 40 \%$ of total precipitation over Greenland (Oltmanns et al., 2019) is likely to be higher if this rainfall-albedo feedback is accounted for in regional climate models.

\subsection{Surface classification change through time}

Repeat UAS acquisitions at S6 showed that the proportional coverage of different surface classes varied significantly from one day to the next (Fig. 5). Over the study period, LA coverage varied by $19 \%$ and HA coverage by $11 \%$. The reduction in snow and CI between 15 and 20 July was caused by rainfall and high winds on 18 and 19 July, which resulted in high sensible heat fluxes (Fig. 3a) and rapid surface melt- ing on 19 July despite low net shortwave radiation (Fig. 3b). Rainfall caused widespread reduction of the thickness of the porous near-surface weathering crust layer and transient cryoconite hole melt out, dispersing cryoconite granules and darkening the surface further (Shimada et al., 2016; Takeuchi et al., 2018). On 20 July only $5 \%$ of the surface was CI, compared to $\sim 10 \%$ on 15 July, with the majority of the area $(87 \%)$ classified as LA or HA. However, the data used to train our classifier have few examples of CI, which is dark due to very thin or absent weathering crusts, so it is likely that some CI surfaces may have been misclassified as LA. Subsequently, CI coverage increased on 21 July and was associated with a $9 \%$ increase in albedo (Fig. 3d) and regrowth of the weathering crust (Fig. 4).

From 21 to 23 July there was relatively little change in proportional surface cover. However, from 23 to 24 July there was a substantial increase in HA, together with the appearance of water and cryoconite and a $10 \%$ albedo reduction (Fig. 3d). Furthermore, variable illumination conditions during the 24 July flight over the western half of the study area caused overestimation of reflectance, likely favouring classification as CI, and so we probably did not capture the full magnitude of surface darkening.

The apparent increase in HA coverage on 24 July was probably not driven entirely by algal growth. Population doubling times are estimated to be $5 \mathrm{~d}$ (Williamson et al., 2018), longer than the $1 \mathrm{~d}$ here. Indeed, LA coverage declined on 24 July while CI remained constant, whereas we would expect both LA and HA to increase in the case of widespread population growth. Instead, cells in LA areas may have been mobilized by the abundant surface meltwater and then deposited downslope in higher concentrations: air temperatures stayed above $0^{\circ} \mathrm{C}$ overnight from 23 to 24 July (Fig. 3b), as- 


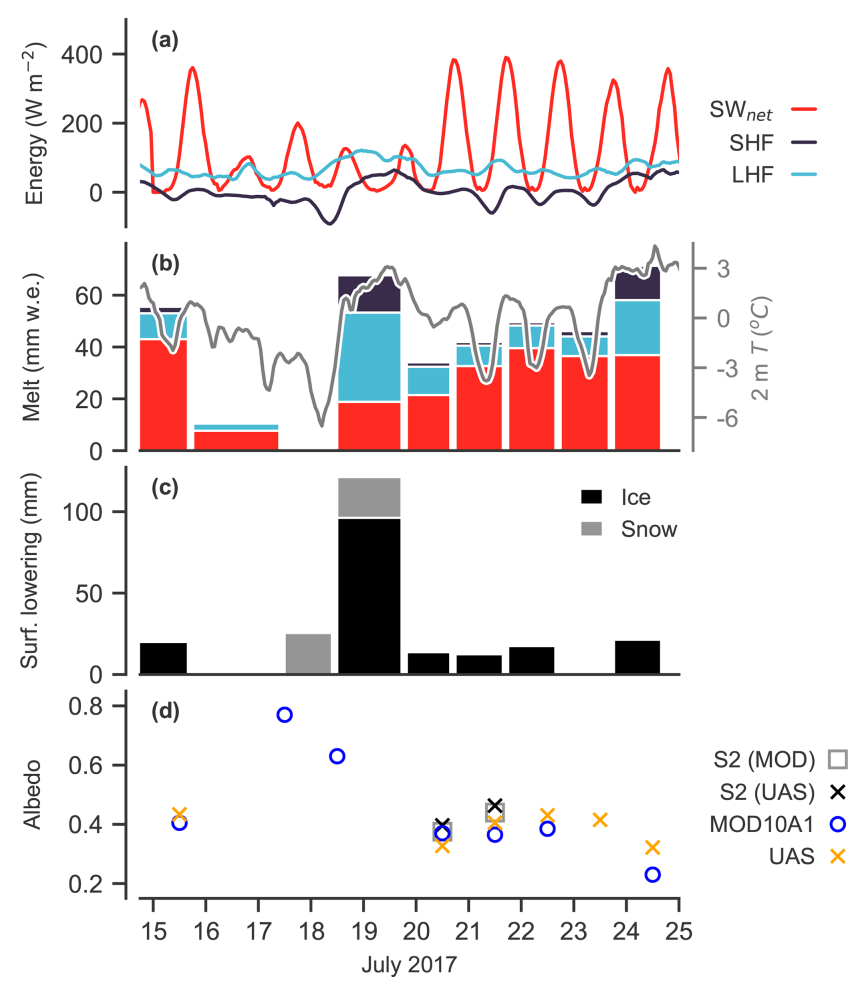

Figure 3. Time series of energy fluxes, models, surface melt rates, surface lowering and sensor albedos. (a) Energy balance components derived from surface energy balance model (Sect. 3.7). (b) Left: melt fluxes in millimetres water equivalent (bars) estimated with surface energy balance model, split into responsible energy flux by colour, for each period of measured surface lowering. Right: $2 \mathrm{~m}$ air temperature (line) from IMAU S6 AWS. (c) Mean measured surface lowering (mm) across the UAS area. (d) Albedo measured by UAS, S-2 within UAS area, S-2 within the MOD10A1 pixels and mean MOD10A1 albedo.

sociated with higher sensible heat fluxes (Fig. 3a), causing the most daily modelled melting of the observation period (Fig. 3b). Furthermore, the sensible heat flux increased the proportion of surface melting relative to sub-surface melting by shortwave penetration, likely thinning the weathering crust and further increasing the amount of liquid meltwater available on the surface, reducing albedo, and increasing the likelihood of misclassification as HA. However, we note that our classification approach relies on coarse surface categories. Any LA ice patch loaded with algae towards the upper bounds of $10^{3}$ cells only needs a relatively small amount of growth to become loaded with $10^{4}$ cells found in HA samples (Sect. 3.5), and so in some pixels the algal population need not have doubled in order to switch from LA to HA. We therefore cannot rule out the role of algae in causing daily surface type changes.

We also found that albedo was a weak predictor of surface class, with considerable overlap in the albedo of the various classes (Fig. 1c, f). Broadband albedo alone is therefore not a reliable predictor of ice surface type and cannot be used to infer the presence of glacier algae or other LAIs.

These findings illustrate that there are two principal reasons why surface classes might change through time: (1) algal growth (and removal, for instance by flushing by meltwater) and (2) physical changes which result in (mis-)classification. We cannot uniquely distinguish between changes caused by algae versus those caused by the weathering crust. First, algal growth is associated with enhanced melting, which reduces the thickness of the weathering crust and liberates liquid water and nutrients, stimulating further growth (Cook et al., 2019a). Second, changes in weathering crust optics occur beneath the algae, so any diagnostic algal feature present in our UAS images may change as the surface microtopography constituting the cell habitat changes. Third, there is uncertainty in spectral biomarkers unique to glacier algae. Theoretically, a simple band ratio, spectral feature identification or spectral mixing technique could be used to detect glacier algae, as has been achieved for snow algae (Takeuchi et al., 2015; Painter et al., 2001; Huovinen et al., 2018). However, absorption by Mesotaenium berggrenii and Ancylonema nordenskiöldii (Williamson et al., 2019), the species found on the GrIS, is dominated by phenolic compounds that absorb strongly across the visible wavelengths (Williamson et al., 2018; Remias et al., 2012) and obscure potentially diagnostic spectral features associated with other algal pigments (Cook et al., 2017, 2019b). A subtle absorption feature related to Chlorophyll $a$ is sometimes detectable using high-spectral-resolution measurements but is not visible in our multi-spectral imagery.

\subsection{Upscaling to satellite scales}

Our measurements at S6 were undertaken coincident with clear-sky observations by S-2 and MODIS MOD10A1. There was generally close agreement between UAS and satellitederived albedo measured at S6 (Fig. 3d). We attribute discrepancies to unavoidable differences between the radiometric calibration and narrowband-broadband conversion techniques and the different degrees of spatial integration. Nevertheless, the direction and magnitude of albedo change between the UAS and S-2 showed good agreement, whilst in general the UAS and MOD10A1 agreed on the direction of albedo changes (Fig. 3d). In the following section we use our UAS data to understand variability in surface type and albedo measured by S-2 and MOD10A1.

\subsubsection{Characterization of sub-S-2-scales}

Sensor spatial resolution is important for algae detection. Classified S-2 data (Fig. 6a, b) show that only CI and LA were identified at $20 \mathrm{~m}$ resolution, whereas at $5 \mathrm{~cm}$ resolution UAS imagery clearly showed frequent patches of HA within any arbitrary $20 \mathrm{~m} \times 20 \mathrm{~m}$ sub-area (Fig. 1b). 

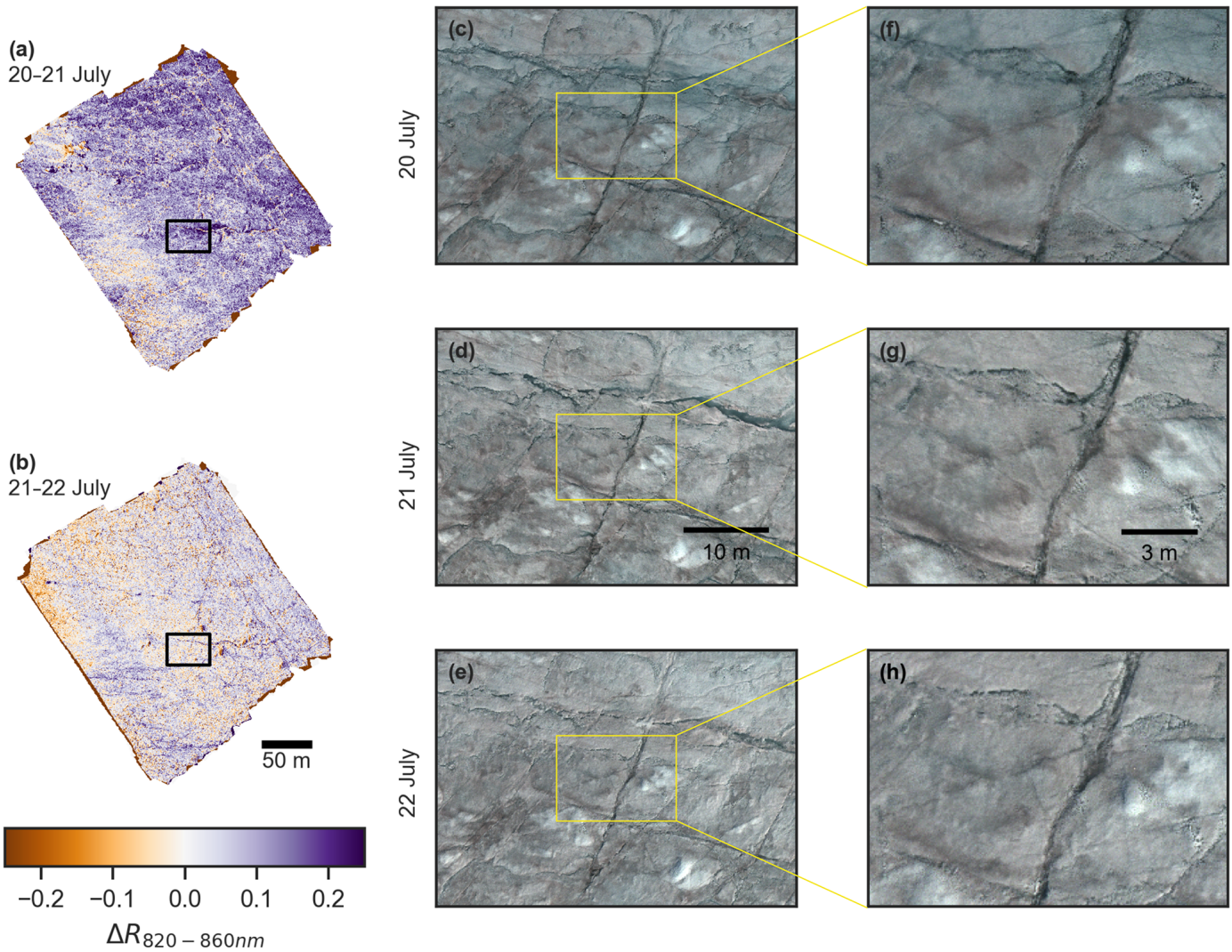

Figure 4. Weathering crust evolution. (a) Change in $840 \mathrm{~nm}$ reflectance between 20 and 21 July 2017: positive values indicate an increase in reflectance from 20 to 21 July. (b) as in (a) but for 21-22 July change. (c-e) RGB true-colour composites of surface within black rectangle shown in panels (a) and (b). (f-h) Zoomed RGB true-colour composites of surface within yellow rectangle in panels (c)-(e). (c, f) 20 July 2017, (d, g) 21 July 2017 and (e, h) 22 July 2017.

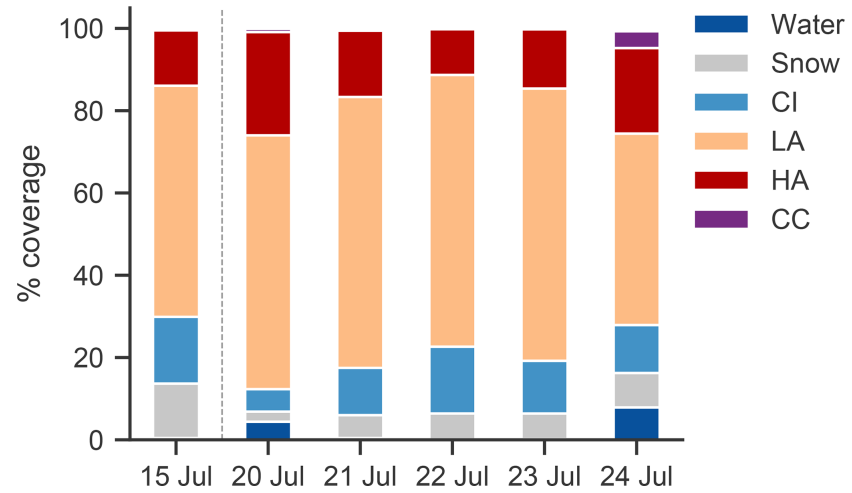

Figure 5. Percentage coverage of each surface type through time at S6.

Fifteen percent of S-2 pixels covering the UAS area changed from LA to CI between 20 and 21 July. We used our UAS data to examine changes in surface class within each S-2 pixel (Table 1). The differences between the S-2 pixels which changed class versus those which did not were small, and S-2 pixels which transitioned to CI continued to be algae-
Table 1. Changes in the sub-S-2-pixel proportional coverage of the main surface classes from 20 to 21 July, aggregated for the S-2 pixels which did not change class (LA $\Rightarrow$ LA) compared to those which $\operatorname{did}(\mathrm{LA} \Rightarrow \mathrm{CI})$. Vertical arrows show direction of change between days.

\begin{tabular}{rrrrrrrrr}
\hline & \multicolumn{2}{c}{ LA $\Rightarrow$ LA } & & \multicolumn{3}{c}{ LA $\Rightarrow$ CI } \\
\cline { 2 - 3 } \cline { 7 - 8 } & 20 July & & 21 July & & 20 July & & 21 July \\
\hline CI & $1 \%$ & $\Uparrow$ & $10 \%$ & & $5 \%$ & $\Uparrow$ & $18 \%$ \\
LA & $59 \%$ & $\Uparrow$ & $65 \%$ & & $73 \%$ & $\Downarrow$ & $68 \%$ \\
HA & $33 \%$ & $\Downarrow$ & $18 \%$ & & $15 \%$ & $\Downarrow$ & $7 \%$ \\
\hline
\end{tabular}

dominated. This demonstrates that the patch dynamics of algal blooms, spatio-temporal variations in snow melt, weathering crust dynamics and surface roughness at sub-S-2-pixel scales $(\sim 1-10 \mathrm{~m})$ are highly relevant for the interpretation of S-2 measurements and hence the attribution of surface melting to specific processes.

Spatial aggregation favours measurement of the mean surface properties. Our measurements suggest that under predominantly snow-free conditions, for an S-2 pixel to be clas- 

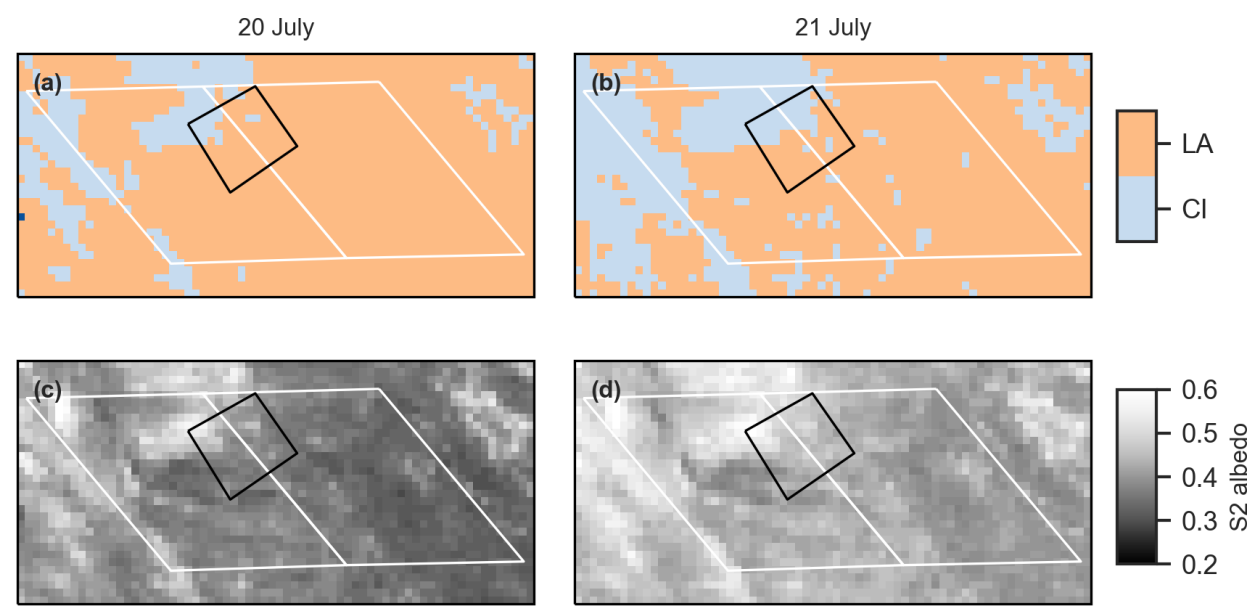

Figure 6. Observations from S-2 in UAS and MODIS areas. (a, b) Surface type classification from S-2. (c, d) Albedo from S-2. (a, c) 20 July and (b, d) 21 July. White rectangles indicate $500 \mathrm{~m}$ MODIS sinusoidal grid pixels covering study area; black rectangles indicate UAS study area.

sified as LA, the majority (> $80 \%$ ) of the pixel needs to be covered in algae, with a significant amount of HA to compensate for the impact of residual CI areas upon the spatial average. We expect that $100 \%$ coverage by LA would also be sufficient to identify algal coverage at S-2 scales, but we cannot show this with our data.

Under reduced shortwave conditions on 20 July there was some evidence of a bi-modal albedo distribution within CI S-2 pixels (Fig. 7a). Once shortwave-dominant conditions returned the albedo distribution became more Gaussian (Fig. 7b). In contrast, the albedo distribution within LA S-2 pixels exhibited unimodal Gaussian characteristics on both days (Fig. 7c, d). Nevertheless, within the LA class there was an appreciable shift from 20 to 21 July to a larger range in sub-S-2-pixel albedo (Fig. 7c, d), highlighting significant variability in sub-pixel albedo. Between 20 and 21 July, $91 \%$ of the UAS study area remained the same or increased in albedo (Fig. 7e). Areas in which albedo declined already had low albedo (as expressed by the colour of each curve in Fig. 7e), while the surfaces which increased in albedo already had high albedo.

It is clear that S-2 estimates of algal growth presence are conservative. This is consistent with Cook et al. (2019b), who found much higher HA coverage in UAV imagery than S-2 imagery due to spatial integration which captures the mean reflectance of the whole area of interest. This suggests that their estimates of spatial coverage by algae over the GrIS western ablation zone and their derived estimate of total runoff attributed to glacier algal growth $(6 \%-9 \%)$ are likely to be conservative. Furthermore, like in our UAS imagery, detection of algae by S-2 is likely to be confounded by changes in the weathering crust which cause optical changes of a similar or greater magnitude than those attributable to glacier algae alone.
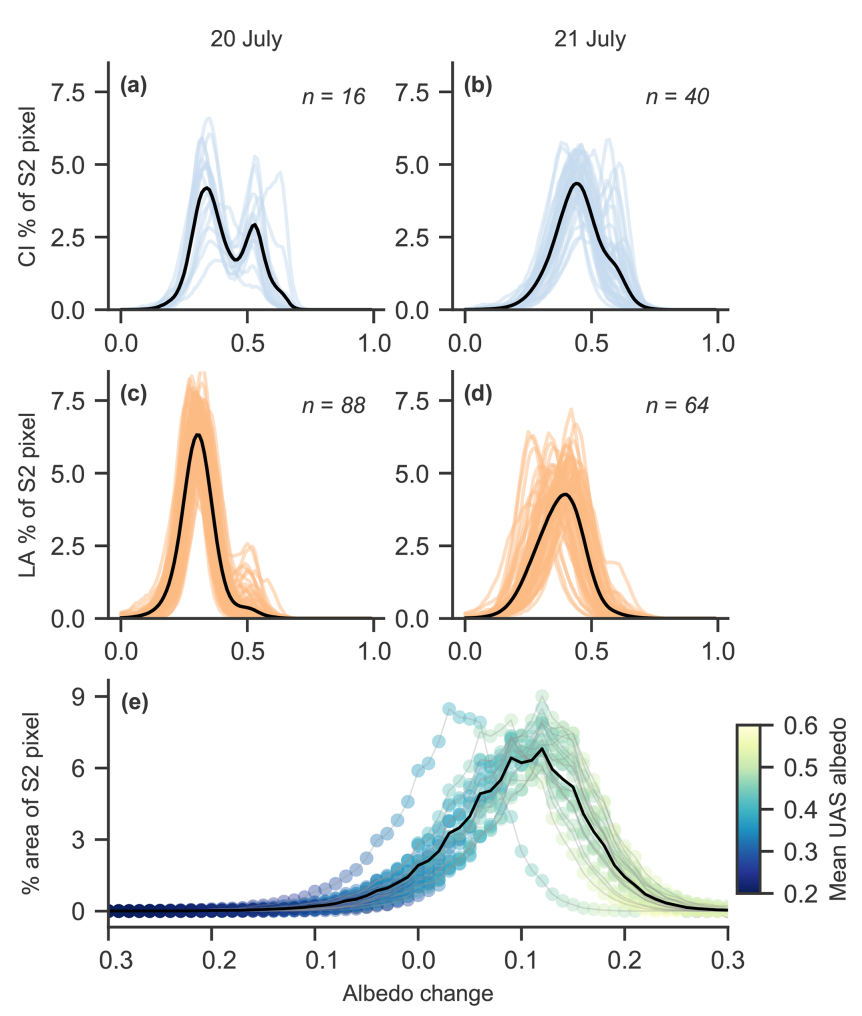

Figure 7. Sub-S-2-pixel albedo distributions derived from UAS measurements. (a-d) Distributions (one line per S-2 pixel), with black line indicating mean albedo distribution; albedo on $x$ axis. (a) Clean-ice pixels on 20 July. (b) Clean-ice pixels on 21 July. (c) Light-algae pixels on 20 July, (d) Light-algae pixels on 21 July. (e) Distributions of albedo change in the pixels which changed class between 20 July and 21 July (one line per pixel) in 0.02 bins. Colour of each bin corresponds to mean albedo of pixels in the bin on 21 July. 


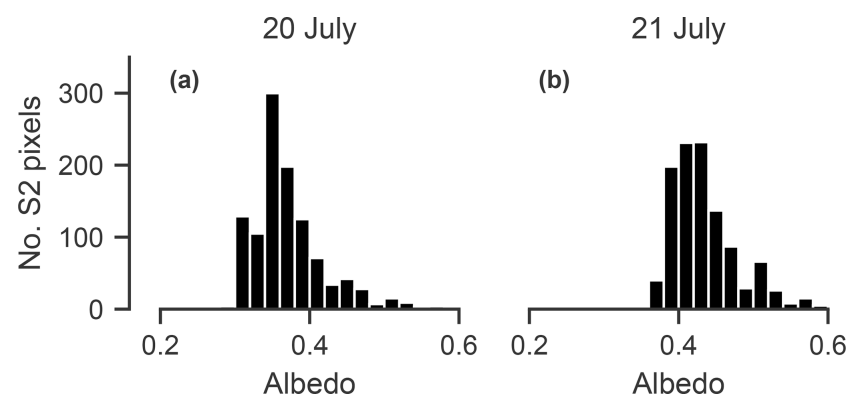

Figure 8. Histograms of S-2-derived albedo within the two MODIS pixels covering the UAS survey area on (a) 20 July and (b) 21 July.

\subsubsection{Characterization of sub-MODIS pixel scales}

The daily MODIS albedo product, MOD10A1, has a coarse spatial resolution of $500 \mathrm{~m}$ and is known to disagree with smaller-scale in situ measurements of albedo at automatic weather stations, especially in the ablation zone (Ryan et al., 2017). This may have ramifications for melt rate calculations that depend on observations of albedo made at coarse spatial resolutions. We used S-2 observations to examine subMODIS-pixel MOD10A1 albedo distributions in the same way that we used UAS data to examine sub-pixel S-2 albedo distributions. For both days of S-2 observations, we examined all $20 \mathrm{~m} \times 20 \mathrm{~m} \mathrm{~S}-2$ pixels that fell inside two MODIS pixels at $\mathrm{S6}$ (Fig. 6).

S-2 albedo within the two MODIS pixels was non-normal and left-skewed on both days of S-2 overpass (Fig. 8). Despite substantial sub-MODIS-pixel changes in albedo there was no net change observed in the mean MOD10A1 albedo of the two pixels (Fig. 4a). Examination of each MODIS pixel separately (Fig. 6) showed that $17 \%$ of the western pixel changed from LA to CI; however, in contrast, MOD10A1 indicated a $1 \%$ albedo decrease, while in the eastern pixel $7 \%$ of the area changed from LA to CI, yet no albedo change was detected by MOD10A1. Albedo increases were measured by S-2 in both MOD10A1 pixels. This demonstrates that low-spectral-resolution and lowspatial-resolution MODIS imagery fails to resolve spatiotemporal patterns of albedo at the surface, and so it cannot be used to attribute melting to specific processes such as weathering crust dynamics, biological growth and decline, impurity accumulation, and supraglacial hydrology.

To estimate the impact of non-normal sub-MODIS-pixel albedo distributions on melt rates we ran our energy balance model in 0.01 albedo increments, with fluxes fixed to those observed at S6 on 21 July at 13:00 local time, to derive an hourly melt rate for each albedo value in the distribution. We then applied these melt rates to each S-2 pixel within the two MODIS pixels as a function of the S-2 pixel's albedo value to estimate the melt flux between 13:00 and 14:00 local time. On 20 July, the distribution-derived melting caused by net shortwave radiation was $241 \mathrm{~m}^{3}$, whereas using the mean albedo computed from all S-2 pixels, it was $236 \mathrm{~m}^{3}$ w.e. On 21 July melting was estimated as 217 and $213 \mathrm{~m}^{3}$ w.e. respectively. The sub-MODIS-scale skew in albedo distribution therefore has a small but non-negligible $(\sim 2 \%)$ difference on estimated surface melting and warrants further investigation over wider spatial and temporal scales.

\section{Conclusions}

Glacier algae are ubiquitous in the two areas of the western GrIS ablation zone that we surveyed. Their local distribution across the ice surface is principally a function of local topography and the characteristics of the surface hydrological network. Rougher surfaces yield local depressions with lower albedos, in which concentrations of algae tend to be higher, suggesting that environmental conditions for growth - especially liquid meltwater presence - are met more readily in these areas and/or that cells which have grown elsewhere can be mobilized and then deposited further downstream. These bio-physical characteristics result in significant albedo variability when compared to smoother ice surfaces where glacier algae tend to be distributed more homogeneously.

The distribution and concentration of algal blooms at local scales change significantly from one day to the next, with "light-algae" surface coverage varying over a range of $19 \%$ during our study at S6. However, algal population sizes require several days to double, and therefore apparent increases in high algal coverage from one day to the next are more likely to principally be the result of local mobilization and redeposition in concentrated patches by supraglacial meltwater flow. Furthermore, whilst glacier algae are potent albedo reducers, daily albedo changes are predominantly associated with physical weathering crust changes controlled by the surface energy budget. The optics of the weathering crust are so dominant over other albedo-affecting processes that under high turbulent heat fluxes, the albedo is principally determined by the state of the weathering crust (i.e. density and porosity, interstitial, and ponded water content). Only under shortwave-dominant energy conditions can a weathering crust develop, enabling LAIs to exert more control upon albedo both directly and by modifying the optics of the underlying ice surface via enhanced melting at patch scales.

Upscaling of our observations to satellite sensor scales shows that Sentinel-2 is conservative in its detection of glacier algae, and so retrievals of algal biomass by Sentinel2 are likely to be underestimated, especially under meteorological conditions that enable widespread development of a weathering crust. Under shortwave-dominant energy conditions, albedo over $20 \mathrm{~m}$ scales (sub-Sentinel-2-pixel) is generally unimodal and unskewed and so is representative of sub-pixel albedo variability. At $500 \mathrm{~m}$ scales, MOD10A1 does not always capture widespread albedo changes measured by other sensors. Sub-MOD10A1 albedo distributions were left-skewed over our bare-ice study area, which is 
equivalent to a $\sim 2 \%$ underestimate in melting derived from surface energy budget calculations, which use only albedo measurements at coarse scales, such as those in the $500 \mathrm{~m}$ MOD10A1 product. Future research should seek to further constrain weathering crust processes and their controls upon albedo and should favour use of higher-spatial-resolution albedo data in heterogeneous ablation zones. 


\section{Appendix A: Overpass times}

Table A1. Times of data acquisition by UAS, S-2 and MODIS (local time, UTC-2). Asterisk indicates variable illumination conditions during UAS flight.

\begin{tabular}{lrrr}
\hline Date & UAS & S-2 & MODIS \\
\hline 15 Jul & $11: 00$ & - & $13: 40$ \\
$20 \mathrm{Jul}$ & $12: 30$ & $12: 59$ & $12: 20$ \\
$21 \mathrm{Jul}$ & $15: 10$ & $13: 19$ & $13: 05$ \\
$22 \mathrm{Jul}$ & $10: 00$ & - & $13: 45$ \\
$23 \mathrm{Jul}$ & $11: 00$ & - & $12: 50$ \\
24 Jul & $13: 00^{*}$ & - & $13: 35$
\end{tabular}

\section{Appendix B: Classifier confusion matrices}

(a) Un-normalized

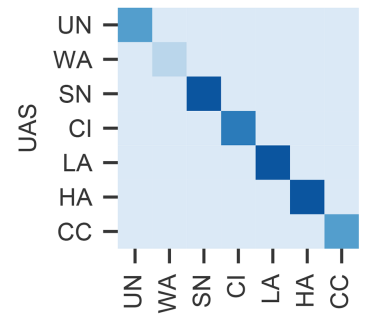

(c)

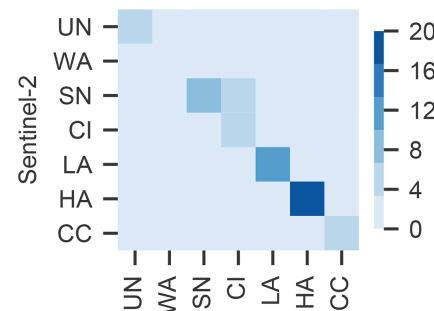

(b) Normalized

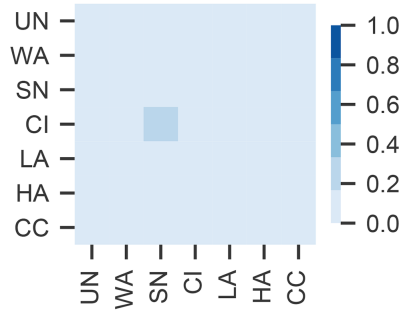

(d)

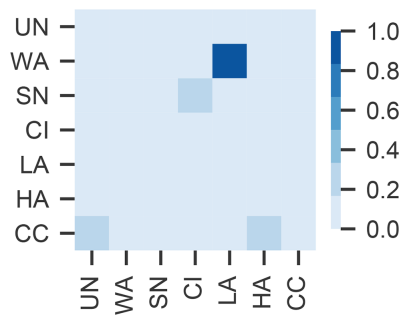

Figure B1. Confusion matrices and normalized confusion matrices for the random-forest models applied to the UAS $(\mathbf{a}, \mathbf{b})$ and Sentinel-2 (c, d) data. Confusion matrices show predicted class on $y$ axis and actual class on $x$ axis. The scores at the intersections show the frequency of instances.

\section{Appendix C: Algal-cell counts at UPE}

Seventy-five biological samples taken at randomized coordinates within the UPE survey area (Sect. 4.1) revealed the widespread presence of glacier algae (Fig. C1). Whether using the cell abundance ranges defined with S6 measurements (Cook et al., 2019b) or using the mean S6 cell abundances to define boundaries between different surface types, it is clear that cell abundances representative of LA and HA coverage were present on the bare-ice surface. Under the bounds-based approach, which enables us to include all of our samples in estimating proportional surface type cover, $80 \%$ of the UPE survey area was algae-covered.

\begin{tabular}{|c|c|c|c|}
\hline Bounds & $20 \%$ & $72 \%$ & \\
\hline $\bar{x} \pm 1 \sigma$ & $23 \%$ & $19 \%$ & $29 \%$ \\
\hline
\end{tabular}

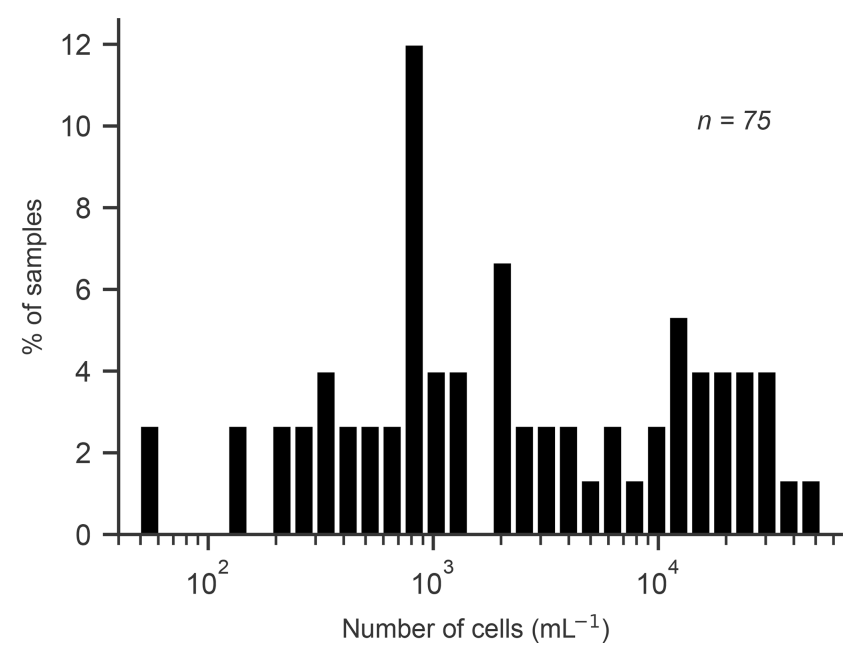

Figure C1. Histogram of cell counts undertaken at UPE on 26 July 2018. The horizontal bars illustrate the range of CI (blue), LA (orange) and HA (red) by two different metrics: (a) "bounds", using the boundaries of $\mathrm{CI}<625$ cells $\mathrm{mL}^{-1}$, HA $>$ $2.9 \times 10^{4}$ cells $\mathrm{mL}^{-1}$, with $\mathrm{LA}$ corresponding to the values between these boundaries, and (b) $\bar{X} \pm 1 \sigma$, which corresponds to the abundance ranges of the surface type classes from S6 reported by Cook et al. (2019b) which were used to train the surface classifier used in this study (Sect. 3.5). Percentage values refer to the number of surface samples which fall into each of these categories. 


\section{Appendix D: Photographs from S6 survey area}
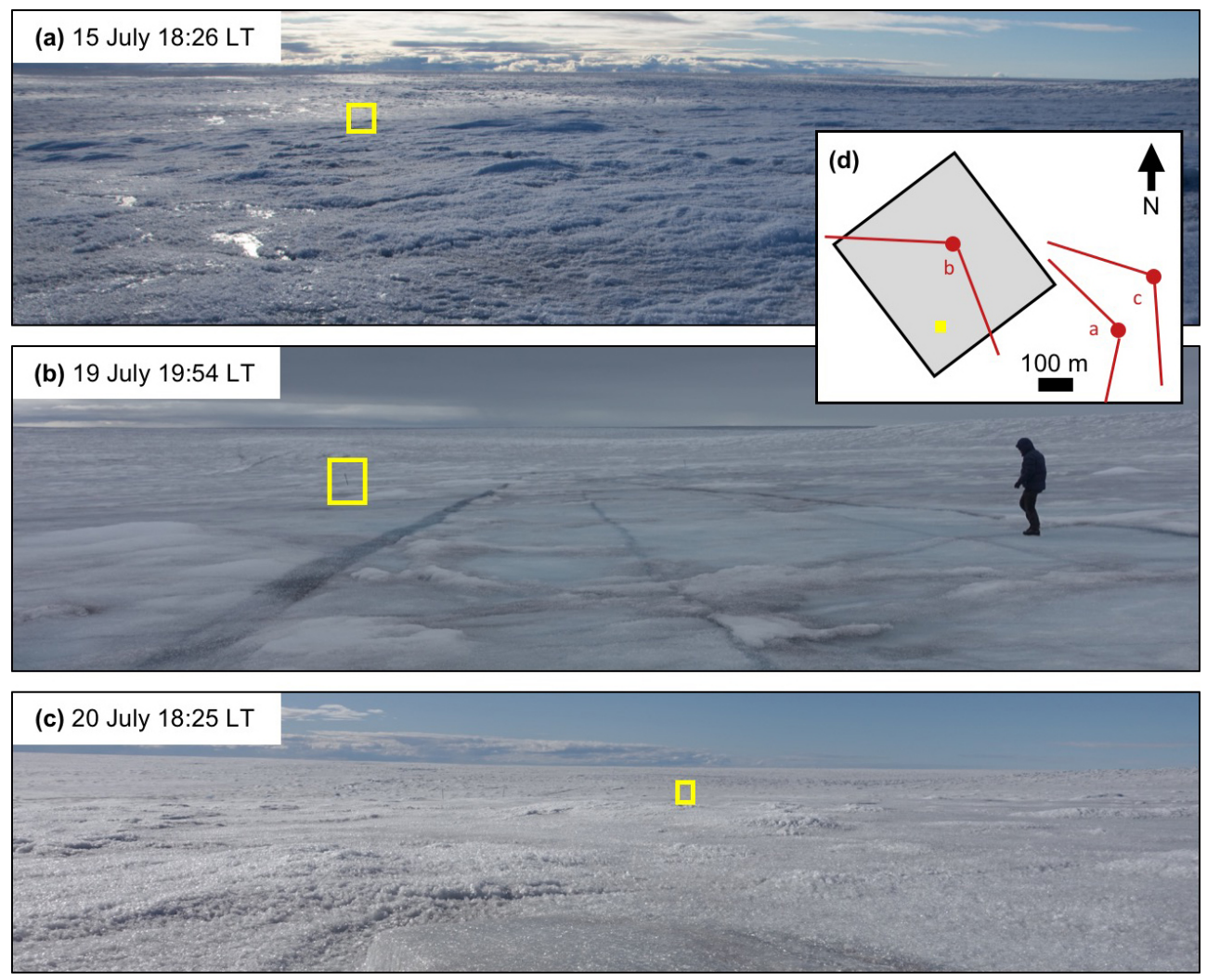

Figure D1. Oblique surface photos of the UAS survey area at S6, all angled approximately west-south-west. Yellow rectangle in each photo shows location of the same $\sim 1.5 \mathrm{~m}$ tall pole used to co-register the photos. All capture times are in local time (LT). (a) 15 July, before snowfall. (b) 19 July, towards the end of stormy conditions that dominated 18-19 July. (c) 20 July, following a return to shortwave-dominant energy balance conditions. (d) Sketch map showing approximate positions from which each photo was taken. UAS survey area indicated by gray box. Location of pole used to co-register images indicated by yellow square.

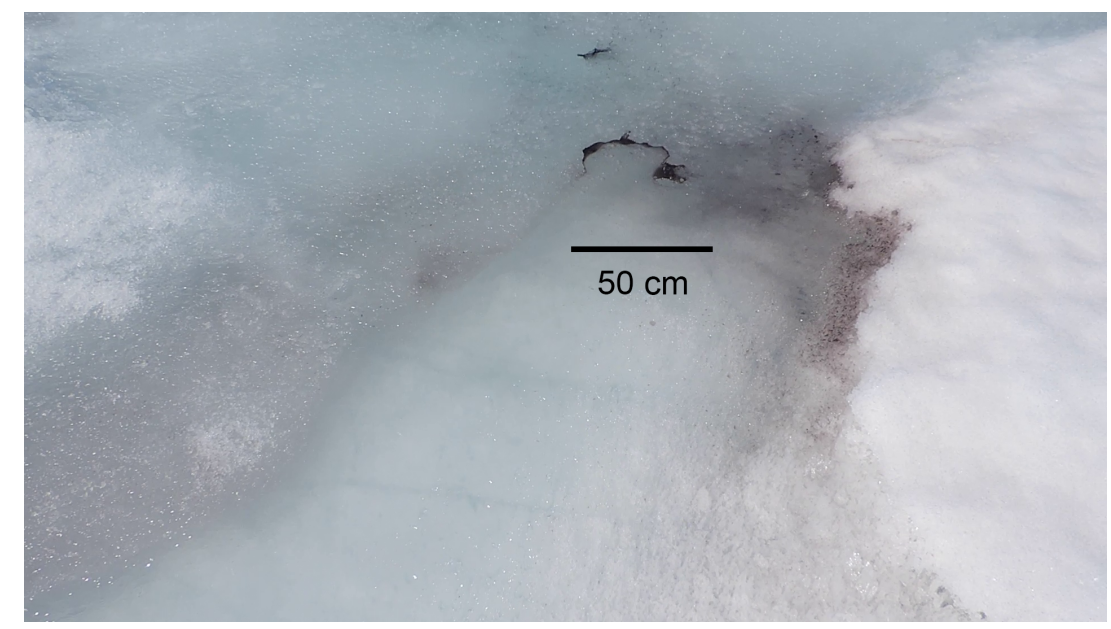

Figure D2. Oblique photograph illustrating locally high concentrations of flushed impurities including glacier algae at a change in gradient of an ephemeral surface stream incised through stagnant snowpack, on 26 June 2017, with approximate scale bar. Photograph taken within $\sim 100 \mathrm{~m}$ of UAS survey area. 
Code and data availability. Code underlying the processing and analysis can be found at https://doi.org/10.5281/zenodo.3598382 (Tedstone, 2020). Processed UAS data for S6 and associated trained classifier can be found at https://doi.org/10.5285/77ca631fa3a4-4f26-bc90-57bb17baa6fc (Tedstone and Cook, 2020b). Processed UAS data for UPE can be found at https://doi.org/10.5285/2dd66461-94af-458f-a9d2-c24bb0bd0322 (Tedstone and Cook, 2020c). Algal-cell counts for UPE can be found at https://doi.org/10.5285/ab953cb8-8675-4a85-b561add6ceba015f (Williamson et al., 2020). Classified Sentinel-2 data can be found at https://doi.org/10.5285/8e0a573d-61a4-4a6f-9fcafc34cbd5fb45 (Tedstone and Cook, 2020a). Unprocessed UAS data for S6 can be found at https://doi.org/10.5285/0579d4a8-e31541d7-af43-25fb50c7d3da (Tedstone and Cook, 2019a), and data for UPE can be found at https://doi.org/10.5285/a87b7897-354c4435-a1bc-e6053e7569e0 (Tedstone and Cook, 2019b). UPE_U AWS data were provided by the Programme for Monitoring of the Greenland Ice Sheet (PROMICE) and the Greenland Analogue Project (GAP) through the Geological Survey of Denmark and Greenland (GEUS) (http://www.promice.dk, last access: 6 February 2020), and S6 AWS data were provided by the Institute for Marine and Atmospheric Research, Utrecht (IMAU, https://www.projects.science.uu.nl/iceclimate/aws/, last access: 6 February 2020). MODIS MOD10A1 data were provided by the National Snow and Ice Data Center (https://doi.org/10.5067/MODIS/MOD10A1.006; Hall and Riggs, 2016), and Sentinel-2 data were provided through Sinergise (https://www.sinergise.com, last access: 10 February 2020) by the European Space Agency SENTINEL Program (http://sentinel.esa.int, last access: 10 February 2020).

Author contributions. AJT and JMC designed the study. JMC built and tested the UAS. AJT, JMC, SH, CJW, JM and TG collected field data. AJT post-processed the UAS imagery. JMC and AJT developed the surface type classification approach. CJW counted the algal cells sampled at the UPE site. AJT analysed the data, produced the figures and wrote the paper. JMC and CJW wrote sections of the paper. All authors commented on the findings and edited the paper.

Competing interests. The authors declare that they have no conflict of interest.

Acknowledgements. Joseph M. Cook acknowledges the Rolex Awards for Enterprise, National Geographic and Microsoft ("AI for Earth"). Thomas Gribbin acknowledges the Gino Watkins Memorial Fund and Nottingham Education Trust. We thank three anonymous reviewers for their comments which improved the paper. In addition to the authors, the "Black and Bloom" project team comprises Alexandre Anesio, Jonathan Bamber, Liane Benning, Edward Hanna, Andrew Hodson, Alexandra Holland, Stefanie Lutz, James McQuaid, Miranda Nicoles, Ewa Sypianska and Marian Yallop.

Financial support. This research has been supported by the Natural Environment Research Council (grant nos. NE/M021025/1 and
NE/M020991/1), the European Research Council (grant no. GlobalMass (694188)) and the Leverhulme Trust (grant no. RF-2018$584 / 4)$.

Review statement. This paper was edited by Moritz Langer and reviewed by three anonymous referees.

\section{References}

Bamber, J. L., Westaway, R. M., Marzeion, B., and Wouters, B.: The land ice contribution to sea level during the satellite era, Environ. Res. Lett., 13, 063008, https://doi.org/10.1088/17489326/aac2f0, 2018.

Barnes, R.: RichDEM: Terrain Analysis Software, Python 0.3.4, hash ee05922, available at: http://github.com/r-barnes/richdem (last access: 10 February 2020), 2016.

Bøggild, C. E., Brandt, R. E., Brown, K. J., and Warren, S. G.: The ablation zone in northeast Greenland: ice types, albedos and impurities, J. Glaciol., 56, 101-113, https://doi.org/10.3189/002214310791190776, 2010.

Brock, B. and Arnold, N.: A spreadsheet-based (Microsoft Excel) point surface energy balance model for glacier and snow melt studies, Earth Surf. Proc. Land., 25, 649-658, 2000.

Christner, B. C., Lavender, H. F., Davis, C. L., Oliver, E. E., Neuhaus, S. U., Myers, K. F., Hagedorn, B., Tulaczyk, S. M., Doran, P. T., and Stone, W. C.: Microbial processes in the weathering crust aquifer of a temperate glacier, The Cryosphere, 12, 3653-3669, https://doi.org/10.5194/tc-12-3653-2018, 2018.

Cook, J. M., Hodson, A. J., and Irvine-Fynn, T. D. L.: Supraglacial weathering crust dynamics inferred from cryoconite hole hydrology, Hydrol. Process., 30, 433-446, 2016.

Cook, J. M., Hodson, A. J., Gardner, A. S., Flanner, M., Tedstone, A. J., Williamson, C., Irvine-Fynn, T. D. L., Nilsson, J., Bryant, R., and Tranter, M.: Quantifying bioalbedo: a new physically based model and discussion of empirical methods for characterising biological influence on ice and snow albedo, The Cryosphere, 11, 2611-2632, https://doi.org/10.5194/tc-11-2611-2017, 2017.

Cook, J. M., Flanner, M., Williamson, C., and Skiles, S.: Biooptical Properties of Terrestrial Snow and Ice, in: Springer Series in Light Scattering, vol. 4: Light Scattering and Radiative Transfer, Springer International Publishing, Cham, 129-163, https://doi.org/10.1007/978-3-030-20587-4_3, 2019a.

Cook, J. M., Tedstone, A. J., Williamson, C., McCutcheon, J., Hodson, A. J., Dayal, A., Skiles, M., Hofer, S., Bryant, R., McAree, O., McGonigle, A., Ryan, J., Anesio, A. M., Irvine-Fynn, T. D. L., Hubbard, A., Hanna, E., Flanner, M., Mayanna, S., Benning, L. G., van As, D., Yallop, M., McQuaid, J., Gribbin, T., and Tranter, M.: Glacier algae accelerate melt rates on the western Greenland Ice Sheet, The Cryosphere Discuss., https://doi.org/10.5194/tc-2019-58, in review, 2019b.

Cooper, M. G., Smith, L. C., Rennermalm, A. K., Miège, C., Pitcher, L. H., Ryan, J. C., Yang, K., and Cooley, S. W.: Meltwater storage in low-density near-surface bare ice in the Greenland ice sheet ablation zone, The Cryosphere, 12, 955-970, https://doi.org/10.5194/tc-12-955-2018, 2018.

Enderlin, E. M., Howat, I. M., Jeong, S., Noh, M.-J., van Angelen, J. H., and van den Broeke, M. R.: An improved mass budget 
for the Greenland ice sheet, Geophys. Res. Lett., 41, 866-872, https://doi.org/10.1002/2013GL059010, 2014.

Fausto, R. S. and van As, D.: Programme for monitoring of the Greenland ice sheet (PROMICE): Automatic weather station data, https://doi.org/10.22008/PROMICE/DATA/AWS, 2019.

Ferguson, R. I.: Sinuosity of Supraglacial streams, Geol. Soc. Am. Bull., 84, 251-256, 1973.

Fettweis, X., Hanna, E., Lang, C., Belleflamme, A., Erpicum, M., and Gallée, H.: Brief communication "Important role of the midtropospheric atmospheric circulation in the recent surface melt increase over the Greenland ice sheet", The Cryosphere, 7, 241248, https://doi.org/10.5194/tc-7-241-2013, 2013.

Greuell, W.: Melt-water Accumulation on the Surface of the Greenland Ice Sheet: Effect on Albedo and Mass Balance, Geogr. Ann. A, 82, 489-498, https://doi.org/10.1111/j.04353676.2000.00136.x, 2000.

Greuell, W., Reijmer, C. H., and Oerlemans, J.: Narrowband-tobroadband albedo conversion for glacier ice and snow based on aircraft and near-surface measurements, Remote Sens. Environ., 82, 48-63, https://doi.org/10.1016/s0034-4257(02)00024$\mathrm{x}, 2002$.

Hall, D. K. and Riggs, G. A.: MODIS/Terra Snow Cover Daily L3 Global 500m Grid, Version 6, [h16v02]. Boulder, Colorado, USA. NASA National Snow and Ice Data Center Distributed Active Archive Center, https://doi.org/10.5067/MODIS/MOD10A1.006, 2016.

Hock, R.: Glacier melt: a review of processes and their modelling, Prog. Phys. Geog., 29, 362-391, https://doi.org/10.1191/0309133305pp453ra, 2005.

Hofer, S., Tedstone, A. J., Fettweis, X., and Bamber, J. L.: Decreasing cloud cover drives the recent mass loss on the Greenland Ice Sheet, Sci. Adv., 3, e1700584, https://doi.org/10.1126/sciadv.1700584, 2017.

Hofmann, H., Kafadar, K., and Wickham, H.: Letter-value plots: Boxplots for large data, Tech. rep., 2011.

Horn, B. K. P.: Hill shading and the reflectance map, P. IEEE, 69, 14-47, 1981.

Huovinen, P., Ramírez, J., and Gómez, I.: Remote sensing of albedo-reducing snow algae and impurities in the Maritime Antarctica, ISPRS J. Photogramm., 146, 507 - 517, https://doi.org/10.1016/j.isprsjprs.2018.10.015, 2018.

Irvine-Fynn, T. D., Bridge, J. W., and Hodson, A. J.: In situ quantification of supraglacial cryoconite morphodynamics using timelapse imaging: an example from Svalbard, J. Glaciol., 57, 651657, https://doi.org/10.3189/002214311797409695, 2011.

Irvine-Fynn, T. D. L., Edwards, A., Newton, S., Langford, H., Rassner, S. M., Telling, J., Anesio, A. M., and Hodson, A. J.: Microbial cell budgets of an Arctic glacier surface quantified using flow cytometry, Environ. Microbiol., 14, 2998-3012, https://doi.org/10.1111/j.1462-2920.2012.02876.x, 2012.

Jonsell, U., Hock, R., and Holmgren, B.: Spatial and temporal variations in albedo on Storglaciären, Sweden, J. Glaciol., 49, 59-68, https://doi.org/10.3189/172756503781830980, 2003.

Knap, W. H. and Reijmer, C. H.: Over Melting Glacier Ice: Measurements in Landsat TM Bands 2 and 4, Remote Sens. Environ., 65, 93-104, 1998.

Knap, W. H., Brock, B., Oerlemans, J., and Willis, I.: Comparison of Landsat TM-derived and ground-based albedos of Haut
Glacier d'Arolla, Switzerland, Int. J. Remote Sens., 20, 32933310, 1999.

Kuipers Munneke, P., Smeets, C. J. P. P., Reijmer, C. H., Oerlemans, J., van de Wal, R. S. W., and van den Broeke, M.: The K-transect on the western Greenland Ice Sheet: surface energy balance (2003-2016), Arct. Antarct. Alp. Res., 50, S100003, https://doi.org/10.1080/15230430.2017.1420952, 2018.

Liang, S.: Narrowband to broadband conversions of land surface albedo I: Algorithms, Remote Sens. Environ., 76, 213-238, https://doi.org/10.1016/S0034-4257(00)00205-4, 2001.

McIntyre, N.: Cryoconite hole thermodynamics, Can. J. Earth Sci., 21, 152-156, https://doi.org/10.1139/e84-016, 1984.

MicaSense: RedEdge Camera Radiometric Calibration Model, available at: https://support.micasense.com/hc/en-us/articles/ 115000351194-RedEdge-Camera-Radiometric-Calibration-Model (last access: 6 February 2020), 2018.

Moustafa, S. E., Rennermalm, A. K., Smith, L. C., Miller, M. A., Mioduszewski, J. R., Koenig, L. S., Hom, M. G., and Shuman, C. A.: Multi-modal albedo distributions in the ablation area of the southwestern Greenland Ice Sheet, The Cryosphere, 9, 905-923, https://doi.org/10.5194/tc-9-905-2015, 2015.

Moustafa, S. E., Rennermalm, A. K., Román, M. O., Wang, Z., Schaaf, C. B., Smith, L. C., Koenig, L. S., and Erb, A.: Evaluation of satellite remote sensing albedo retrievals over the ablation area of the southwestern Greenland ice sheet, Remote Sens. Environ., 198, 115-125, https://doi.org/10.1016/j.rse.2017.05.030, 2017.

Muller, F. and Keeler, C. M.: Errors in short-term ablation measurements on melting glacier surfaces, J. Glaciol., 8, 91-105, 1969.

Munro, D. S.: Comparison of Melt Energy Computations and Ablatometer Measurements on Melting Ice and Snow, Arctic Alpine Res., 22, 153-162, 1990.

Noël, B., van de Berg, W. J., van Meijgaard, E., Kuipers Munneke, P., van de Wal, R. S. W., and van den Broeke, M. R.: Evaluation of the updated regional climate model RACMO2.3: summer snowfall impact on the Greenland Ice Sheet, The Cryosphere, 9, 1831-1844, https://doi.org/10.5194/tc-9-1831-2015, 2015.

Oltmanns, M., Straneo, F., and Tedesco, M.: Increased Greenland melt triggered by large-scale, year-round cyclonic moisture intrusions, The Cryosphere, 13, 815-825, https://doi.org/10.5194/tc13-815-2019, 2019.

Painter, T. H., Duval, B., Thomas, W. H., Mendez, M., Heintzelman, S., and Dozier, J.: Detection of quantification of snow algae with an Airborne Imaging Spectrometer, Appl. Environ. Microbiol., 67, 5267-5272, 2001.

Remias, D., Schwaiger, S., Aigner, S., Leya, T., Stuppner, H., and Lütz, C.: Characterization of an UV- and VISabsorbing, purpurogallin-derived secondary pigment new to algae and highly abundant in Mesotaenium berggrenii (Zygnematophyceae, Chlorophyta), an extremophyte living on glaciers, FEMS Microbiol. Ecol., 79, 638-648, https://doi.org/10.1111/j.1574-6941.2011.01245.x, 2012.

Ryan, J. C., Hubbard, A., Irvine-Fynn, T. D., Doyle, S. H., Cook, J. M., Stibal, M., and Box, J. E.: How robust are in-situ observations for validating satellite-derived albedo over the dark zone of the Greenland Ice Sheet?, Geophys. Res. Lett., 44, 6218-6225, https://doi.org/10.1002/2017GL073661, 2017.

Ryan, J. C., Hubbard, A., Stibal, M., Irvine-Fynn, T., Cook, J., Smith, L. C., Cameron, K., and Box, J. E.: Dark 
zone of the Greenland Ice Sheet controlled by distributed biologically-active impurities, Nat. Commun., 9, 1065, https://doi.org/10.1038/s41467-018-03353-2, 2018.

Ryan, J. C., Smith, L. C., van As, D., Cooley, S. W., Cooper, M. G., Pitcher, L. H., and Hubbard, A.: Greenland Ice Sheet surface melt amplified by snowline migration and bare ice exposure, Sci. Adv., 5, eaav3738, https://doi.org/10.1126/sciadv.aav3738, 2019.

Schuler, T.: Diurnal variability of subglacial drainage conditions as revealed by tracer experiments, J. Geophys. Res., 109, 1-13, https://doi.org/10.1029/2003JF000082, 2004.

Schuster, C.: Weathering crust processes on melting glacier ice (Alberta, Canada), PhD thesis, Wilfri Laurier University, 2001.

Shimada, R., Takeuchi, N., and Aoki, T.: Inter-annual and geographical variations in the extent of bare ice and dark ice on the Greenland ice sheet derived from MODIS satellite images, Front. Earth Sci., 4, https://doi.org/10.3389/feart.2016.00043, 2016.

Steger, C. R., Reijmer, C. H., and van den Broeke, M. R.: The modelled liquid water balance of the Greenland Ice Sheet, The Cryosphere, 11, 2507-2526, https://doi.org/10.5194/tc-11-25072017, 2017.

Stibal, M., Box, J. E., Cameron, K. A., Langen, P. L., Yallop, M. L., Mottram, R. H., Khan, A. L., Molotch, N. P., Chrismas, N. A. M., Calì Quaglia, F., Remias, D., Smeets, C. J. P. P., van den Broeke, M. R., Ryan, J. C., Hubbard, A., Tranter, M., van As, D., and Ahlström, A. P.: Algae Drive Enhanced Darkening of Bare Ice on the Greenland Ice Sheet, Geophys. Res. Lett., 44, 11463-11471, https://doi.org/10.1002/2017GL075958, 2017.

Takeuchi, N., Fujisawa, Y., Kadota, T., Tanaka, S., Miyairi, M., Shirakawa, T., Kusaka, R., Fedorov, A. N., Konstantinov, P., and Ohata, T.: The effect of impurities on the surface melt of a glacier in the Suntar Khayata Mountain Range, Russian Siberia, Front. Earth Sci., 3, https://doi.org/10.3389/feart.2015.00082, 2015.

Takeuchi, N., Sakaki, R., Uetake, J., Nagatsuka, N., Shimada, R., Niwano, M., and Aoki, T.: Temporal variations of cryoconite holes and cryoconite coverage on the ablation ice surface of Qaanaaq Glacier in northwest Greenland, Ann. Glaciol., 59, 2130, https://doi.org/10.1017/aog.2018.19, 2018

Tedesco, M., Doherty, S., Fettweis, X., Alexander, P., Jeyaratnam, J., and Stroeve, J.: The darkening of the Greenland ice sheet: trends, drivers, and projections (1981-2100), The Cryosphere, 10, 477-496, https://doi.org/10.5194/tc-10-477-2016, 2016.

Tedstone, A.: atedstone/GrIS_ice_albedo_variability: Code for study analysis, Zenodo, https://doi.org/10.5281/zenodo.3598382, 2020.

Tedstone, A. and Cook, J.: Multi-spectral unmanned aerial system imagery, S6, south-west Greenland, July 2017: Level 1 (unmosaiced radiance measurements) [Data set], UK Polar Data Centre, Natural Environment Research Council, UK Research \& Innovation, https://doi.org/10.5285/0579d4a8-e31541d7-af43-25fb50c7d3da, 2019a.

Tedstone, A. and Cook, J.: Multi-spectral unmanned aerial system imagery, UPE_U, north-west Greenland, July 2018: Level 1 (unmosaiced radiance measurements) [Data set], UK Polar Data Centre, Natural Environment Research Council, UK Research \& Innovation, https://doi.org/10.5285/a87b7897-354c4435-a1bc-e6053e7569e0, 2019b.

Tedstone, A. and Cook, J.: Sentinel-2 imagery, S6, southwest Greenland, July 2017: Broadband albedo and sur- face type classification [Data set], UK Polar Data Centre, Natural Environment Research Council, UK Research \& Innovation, https://doi.org/10.5285/8e0a573d-61a4-4a6f-9fcafc34cbd5fb45, 2020a.

Tedstone, A. and Cook, J.: Multi-spectral unmanned aerial system imagery, S6, south-west Greenland, July 2017: Levels 2 (ground reflectance) and 3 (broadband albedo and surface type classification) [Data set], UK Polar Data Centre, Natural Environment Research Council, UK Research \& Innovation, https://doi.org/10.5285/77ca631f-a3a44f26-bc90-57bb17baa6fc, 2020b.

Tedstone, A. and Cook, J.: Multi-spectral unmanned aerial system imagery, UPE_U, north-west Greenland, July 2018: Levels 2 (ground reflectance) and 3 (broadband albedo and surface type classification) [Data set], UK Polar Data Centre, Natural Environment Research Council, UK Research \& Innovation, https://doi.org/10.5285/2dd66461-94af458f-a9d2-c24bb0bd0322, 2020c.

Tedstone, A. J., Bamber, J. L., Cook, J. M., Williamson, C. J., Fettweis, X., Hodson, A. J., and Tranter, M.: Dark ice dynamics of the south-west Greenland Ice Sheet, The Cryosphere, 11, 24912506, https://doi.org/10.5194/tc-11-2491-2017, 2017.

Uetake, J., Naganuma, T., Hebsgaard, M. B., Kanda, H., and Kohshima, S.: Communities of algae and cyanobacteria on glaciers in west Greenland, Polar Sci., 4, 71-80, https://doi.org/10.1016/j.polar.2010.03.002, 2010.

United States Geological Survey: Unmanned Aerial Systems Data Post-Processing: Struture-from-Motion Photogrammetry. Section 2: MicaSense 5-band Multispectral Imagery, available at: https://uas.usgs.gov/nupo/pdf/ PhotoScanProcessingMicaSenseMar2017.pdf (last access: 6 February 2020), 2017.

van As, D., Fausto, R. S., Ahlstrom, A. P., Andersen, S. B., Andersen, M. L., Citterio, M., Edelvang, K., Gravesen, P., Machguth, H., Nick, F. M., Nielsen, S., and Weidick, A.: Programme for Monitoring of the Greenland Ice Sheet (PROMICE): first temperature and ablation records, Geol. Surv. Den. Greenl., 23, 73-76, 2011.

van den Broeke, M., Box, J. E., Fettweis, X., Hanna, E., Noël, B., Tedesco, M., van As, D., van de Berg, W. J., and van Kampenhout, L.: Greenland Ice Sheet Surface Mass Loss: Recent Developments in Observation and Modelling, Curr. Clim. Change Rep., 3, 345-356, https://doi.org/10.1007/s40641-017-0084-8, 2017.

Wang, S., Tedesco, M., Xu, M., and Alexander, P. M.: Mapping Ice Algal Blooms in Southwest Greenland From Space, Geophys. Res. Lett., 45, 11779-11788, https://doi.org/10.1029/2018GL080455, 2018.

Warren, S. G.: Impurities in snow: effects on albedo and snowmelt, Ann. Glaciol., 5, 177-179, 1984.

Wientjes, I. G. M. and Oerlemans, J.: An explanation for the dark region in the western melt zone of the Greenland ice sheet, The Cryosphere, 4, 261-268, https://doi.org/10.5194/tc-4-261-2010, 2010.

Williamson, C. J., Anesio, A. M., Cook, J., Tedstone, A., Poniecka, E., Holland, A., Fagan, D., Tranter, M., and Yallop, M. L.: Ice algal bloom development on the surface of the Greenland Ice Sheet, FEMS Microbiol. Ecol., 94, fiy025, https://doi.org/10.1093/femsec/fiy025, 2018. 
Williamson, C. J., Cameron, K. A., Cook, J. M., Zarsky, J. D., Stibal, M., and Edwards, A.: Glacier Algae: A Dark Past and a Darker Future, Front. Microbiol., 10, 524, https://doi.org/10.3389/fmicb.2019.00524, 2019.

Williamson, C. J., Tedstone, A. and Cook, J.: Glacier algae cell counts from UPE_U, north-west Greenland, 26 July 2018 [Data set], UK Polar Data Centre, Natural Environment Research Council, UK Research \& Innovation, https://doi.org/10.5285/ab953cb8-8675-4a85-b561add6ceba015f, 2020.
Yallop, M. L., Anesio, A. M., Perkins, R. G., Cook, J., Telling, J., Fagan, D., MacFarlane, J., Stibal, M., Barker, G., Bellas, C., Hodson, A., Tranter, M., Wadham, J., and Roberts, N.: Photophysiology and albedo-changing potential of the ice algal community on the surface of the Greenland ice sheet, ISME J., 6 , 2302-2313, https://doi.org/10.1038/ismej.2012.107, 2012.

Zuo, Z. and Oerlemans, J.: Modelling albedo and specific balance of the Greenland ice sheet: calculations for the Sondre Stromfjord transect, J. Glaciol., 42, 305-317, 1996. 